\title{
The nematode community in the Atlantic rainforest lizard Enyalius perditus Jackson, 1978 from south-eastern Brazil
}

\author{
A.F. Barreto-Lima ${ }^{1 *}$, G.M. Toledo ${ }^{2}$ and L.A. Anjos ${ }^{2}$ \\ ${ }^{1}$ UFRGS - Universidade Federal do Rio Grande do Sul - Instituto de \\ Biociências, Programa de Pós-Graduação em Ecologia, Avenida Bento \\ Gonçalves, n 9500, Setor 4, Prédio 43422, Bairro Agronomia, Caixa Postal \\ 15007, Porto Alegre, Rio Grande do Sul, Brazil: ${ }^{2}$ UNESP - Universidade \\ Estadual Paulista, Campus de Botucatu - Instituto de Biociências, \\ Departamento de Parasitologia, Botucatu, São Paulo, Brazil
}

(Received 10 March 2011; Accepted 4 September 2011; First Published Online 11 October 2011)

\begin{abstract}
Studies focusing on communities of helminths from Brazilian lizards are increasing, but there are many blanks in the knowledge of parasitic fauna of wild fauna. This lack of knowledge hampers understanding of ecological and parasitological aspects of involved species. Moreover, the majority of research has focused on parasitic fauna of lizards from families Tropiduridae and Scincidae. Only a few studies have looked at lizards from the family Leiosauridae, including some species of Enyalius. This study presents data on the gastrointestinal parasite fauna of Enyalius perditus and their relationships with ecological aspects of hosts in a disturbed Atlantic rainforest area in the state of Minas Gerais, south-eastern Brazil. Two nematode species, Oswaldocruzia burseyi [(Molineidae) and Strongyluris oscari (Heterakidae) were found. Nematode species showed an aggregated distribution in this host population, with O. burseyi being more aggregated than $S$. oscari. The present study extends the range of occurrence of $O$. burseyi to the Brazilian continental area.
\end{abstract}

\section{Introduction}

The host-parasite relationship is an important parameter in the study of animal communities, as such relationships affect population dynamics and community structure (Rocha et al., 2000; Anjos et al., 2005; Almeida et al., 2009). The helminth fauna of lizards in South America has received greater attention in recent years, with many records of new hosts and localities as well as the description of new species (Goldberg et al., 2004; Bursey et al., 2005a, b; Durette-Desset et al., 2006; Bursey \& Goldberg, 2007; Vrcibradic et al., 2008; Ávila \& Silva, 2010). Nevertheless, studies on helminth communities and ecological aspects of host-parasite relationships

*E-mail: afblima@hotmail.com remain scarce in the literature (Rocha \& Vrcibradic, 2003; Anjos et al., 2005) and greater knowledge on the parasitological and ecological features of different lizard species is needed.

The genus Enyalius Wied, 1821 is comprised of nine species (Sociedade Brasileira de Herpetologia, 2010) of diurnal, insectivorous lizards (Sousa \& Cruz, 2008; Barreto-Lima, 2009) well distributed throughout different biomes in Brazil, such as the Atlantic rainforest (Etheridge, 1969; Vanzolini, 1972, 1974; Jackson, 1978), Amazon (Ávila-Pires, 1995; Vitt et al., 1996), Caatinga (semi-arid brush) and Cerrado (savanna-like vegetation) (Bertolotto et al., 2002; Rodrigues et al., 2006). Despite the wide distribution of Enyalius, few studies have addressed its helminth fauna and parasite ecology (Vicente et al., 1993; Durette-Desset et al., 2006; Sousa et al., 2007; Vrcibradic et al., 2007, 2008). Enyalius perditus 
Jackson, 1978 is a small tropical lizard restricted to the easternmost Atlantic rainforest in southern and southeastern Brazil (Jackson, 1978; Lima \& Sousa, 2006) that has been insufficiently studied with regard to many ecological and behavioural aspects (Lima \& Sousa, 2006).

As infection parameters, such as the prevalence and number of parasites, may be influenced by the sex, age, size (Ribas et al., 1995) and diet composition (Goldberg et al., 1993, 1995) of the host, the aim of the present study was to analyse helminth fauna from the gastrointestinal tract of E. perditus and determine the relationship between ecological aspects of the host, such as body mass, sex and size, and the parasitic fauna.

\section{Materials and methods \\ Host and parasite sampling}

Lizards were collected with pitfall traps in a forest fragment of the Santa Cândida Municipal Biological Reserve $\left(21^{\circ} 45^{\prime} 35^{\prime \prime} \mathrm{S}, 43^{\circ} 20^{\prime} 50^{\prime \prime} \mathrm{W}\right)$ in the city of Juiz de Fora, state of Minas Gerais, Brazil, between 2002 and 2003. The lizard species were identified based on Rodrigues et al. (2006). Animals were weighed on a manual scale (accuracy: $0.10 \mathrm{~g}$ ), euthanized with ether, fixed in a $10 \%$ formalin solution and stored in $70 \%$ ethanol. Snout-vent length (SVL), total body length (TBL) and tail length (TL) were measured with a caliper to the nearest $0.1 \mathrm{~mm}$. Gonads were examined to determine the sex. The gastrointestinal tract (stomach, small and large intestines) was removed and examined for helminths under a stereomicroscope. Nematodes were removed, counted, treated with lactophenol for clarification and examined under an optical microscope (Leica ${ }^{\circledR}$ DM5000B), using the LAS software program (Leica Application Suite) for image analysis. The prevalence and mean intensity of infection of each nematode species were determined based on Bush et al. (1997).

\section{Data analysis}

Differences in body size and mean intensity of infection between sexes were determined using the MannWhitney test and Student's t-test, respectively. A test for proportions (Z-test) was used to determine whether there was a significant difference in overall prevalence between males and females (Zar, 1999). A Spearman rank correlation (Zar, 1999) was performed to evaluate the effect of host size (SVL) on the intensity of infection. A Spearman rank correlation was performed to evaluate the relationship between body mass and intensity of infection, using the residual values obtained from linear regression analysis between TL and body mass (Zar, 1999). The discrepancy index $(D)$ was calculated, as suggested by Poulin (1993). This index has a minimum of zero $(D=0)$ when every host harbours the same number of parasites. When all parasites are found in a single host, aggregation is maximal $(D=1)$. This index was calculated using the Quantitative Parasitology 3.0 software program (Rózsa et al., 2000). For all tests, the level of significance was $\alpha \leq 0.05$. Voucher specimens of the lizard hosts were deposited in the Herpetological Collection of the Zoology Laboratory of the Universidade

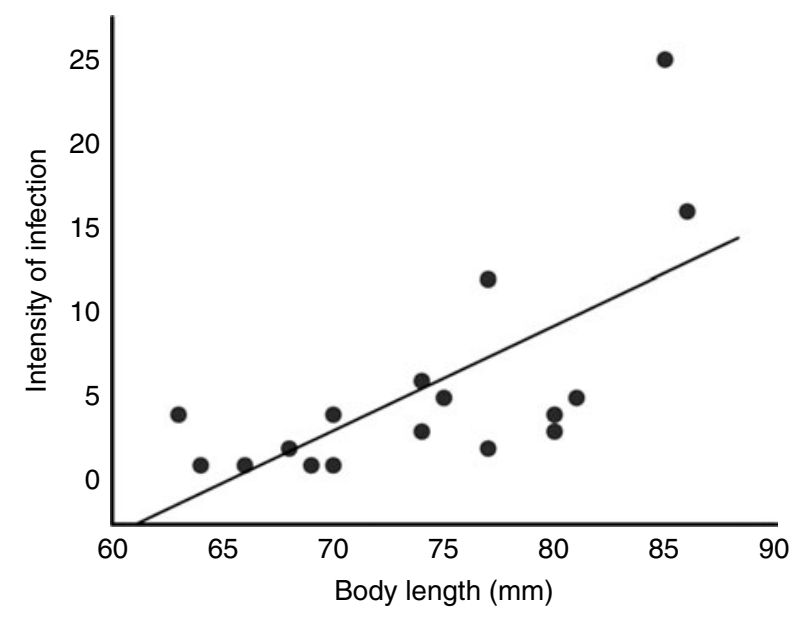

Fig. 1. Regression between body length and intensity of infection of Enyalius perditus from Reserva Biológica Municipal Fazenda Santa Cândida, Juiz de Fora municipality, Minas Gerais state, Brazil.

Federal de Juiz de Fora (1-5s/n.2002/UFJF, 59-61.2002/ UFJF, 233-240 CZ/UFJF, 243 CZ/UFJF, 245-255 CZ/ UFJF, 257-275 CZ/UFJF) and parasite specimens were deposited in the Coleção Helmintológica do Instituto de Biociências de Botucatu (CHIBB Lotes nos 5099 and 6000).

\section{Results}

Forty-nine specimens of E. perditus (31 males and 18 females) were examined: 27 adult males (SVL $=72.2$ $\pm 5.2 \mathrm{~mm} ; \quad$ mass $=8.7 \pm 2.2 \mathrm{~g}), 15$ adult females $(\mathrm{SVL}=83.8 \pm 6.9 \mathrm{~mm} ;$ mass $=15.9 \pm 6.4 \mathrm{~g})$ and seven juveniles $(\mathrm{SVL}=37.4 \pm 5.7 \mathrm{~mm}$; mass $=1.5 \pm 0.9 \mathrm{~g})$. Size and body mass were different between adult males and

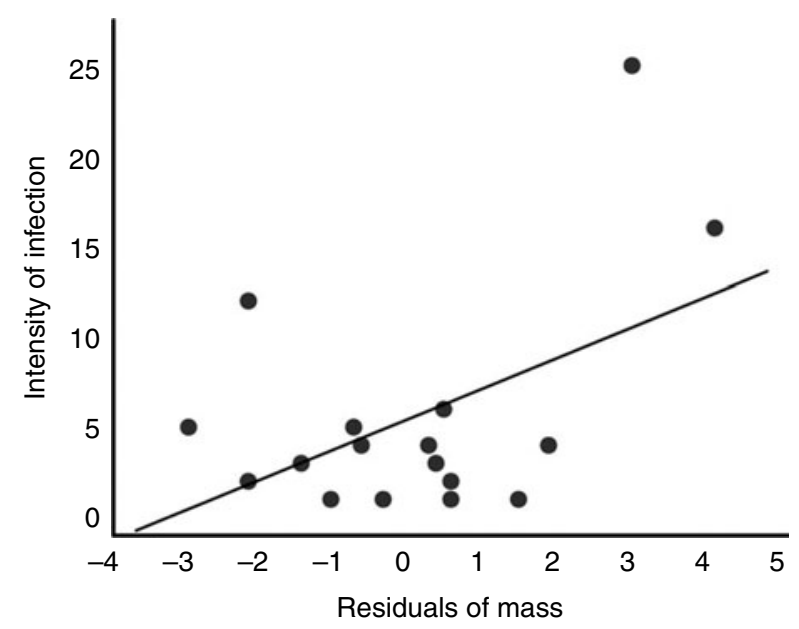

Fig. 2. Regression between mass (independent of total body length) and intensity of infection of Enyalius perditus from Reserva Biológica Municipal Fazenda Santa Cândida, Juiz de Fora municipality, Minas Gerais state, Brazil. 
adult females (SVL: $Z(U)=3.5, P<0.001$; body mass $=$ $Z(U)=2.2, P<0.05)$.

The overall prevalence of parasites was 55.1\% (27/49): $70.4 \%$ in adult males, $40.0 \%$ in adult females and $28.6 \%$ in juveniles. The difference between the prevalence of parasites in adult males and adult females was nonsignificant $(Z=1.59, P=0.11)$. Mean intensity of infection was $7.1 \pm 6.8$ (range: $1-26$ ). The mean intensity of infection was $11.3 \pm 8.9$ in adult females and $6.3 \pm 6.0$ in adult males. However, this difference did not achieve statistical significance $(t=1.61, \mathrm{df}=23, P=0.12)$. Two juvenile lizards were infected by two and four nematodes. The body size (SVL) of adult lizards was positively associated with the intensity of infection $(F=12.74$, $P=0.003, r^{2}=0.423$ ) (fig. 1). After adjusting for the effect of total body length (residual between TBL $\times$ mass), body mass of the adult hosts was positively associated with the intensity of infection $(F=4.68 ; \quad P=0.045$; $r^{2}=0.187$ ) (fig. 2).

Two nematode species were found in the stomach, small intestine and large intestine of lizards: Oswaldocruzia burseyi Duretter-Desset, Anjos \& Vrcibradic, 2006 (Molineidae) and Strongyluris oscari Travassos, 1923
(Heterakidae). The prevalence of 0 . burseyi was $62.7 \%$ $(n=17)$, with a mean intensity of infection of $3.1 \pm 2.9$ (range 1-12) and discrepancy index of 0.621 . The prevalence of $S$. oscari was $74.1 \%(n=20)$, with a mean intensity of infection of $6.75 \pm 6.4$ (range $1-25$ ) and discrepancy index of 0.572 . The prevalence of these two nematode species was similar $(Z=0.586 ; P=0.558)$. However, $S$. oscari exhibited a significantly higher mean intensity of infection $(t=-2.3 ; P=0.03)$. The discrepancy index $(D)$ for both parasite species was 0.647 (O.burseyi, 0.621; S. oscari, 0.572).

\section{Discussion}

Lizards are hosts to a wide variety of gastrointestinal nematodes (Goldberg \& Bursey, 1992). The cosmopolitan genus Oswaldocruzia Travassos, 1917 parasitizes amphibians (Durette-Desset et al., 2006) and lizards from several families, such as Gekkonidae, Gymnphthalmidae, Iguanidae, Leiosauridae, Polychrotidae, Teiidae and Tropiduridae (Ávila \& Silva, 2010). Oswaldocruzia nematodes are common parasites of lizards and new species have

Table 1. Helminth fauna of Enyalius spp. from Brazil; P(\%), prevalence, MI, mean intensity of infection ( \pm standard deviation).

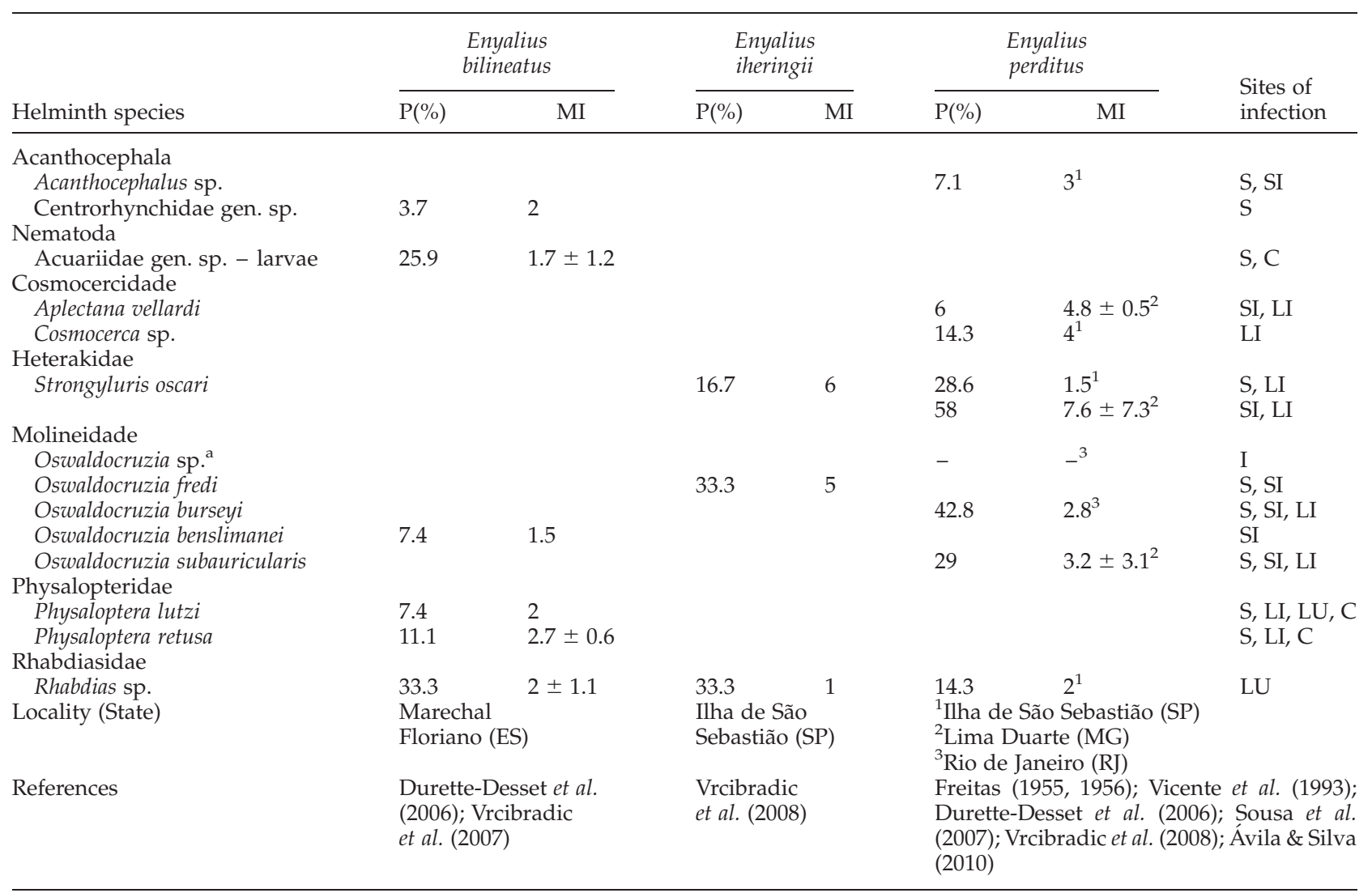

Sites of infection: S, stomach, SI, small intestine; LI, large intestine; I, intestine; C, body cavity; LU, lungs.

Localities: ES, Espírito Santo State; MG, Minas Gerais; RJ, Rio de Janeiro State; SP, Sāo Paulo State.

Rhabdias sp. was found in E. catenatus in the Ibateguara locality, Alagoas state, by Freire $(2008): \mathrm{P}(\%)=36.4, \mathrm{MI}=3.7( \pm 6.3)$.

${ }^{a}$ Oswaldocruzia subauricularis from the host Enyalius catenatus (without data), in Freitas (1955 and, probably, 1956) are both considered as species inquirenda by Durette-Desset et al. (2006), and Enyalius catenatus was described as Enyalius perditus by Jackson (1978). 
been described infecting Enyalius, such as two new species of Oswaldocruzia sampled from the stomach and small intestine of E. iheringii and E. perditus on São Sebastião Island off the state of São Paulo, Brazil (DuretteDesset et al., 2006) (table 1). Vrcibradic et al. (2008) reported that helminth assemblages in E. perditus and E. iheringii on São Sebastião Island were depauperate and dominated by generalist helminths with direct life cycles. It is important to note that the host species E. catenatus analysed by Freitas (1955) was later described as E. perditus by Jackson (1978) and its nematode species O. subauricularis was misidentified and is considered a species inquirenda by Durette-Desset et al. (2006).

Oswaldocruzia burseyi was initially recorded for an island habitat (São Sebastião Island) (Vrcibradic et al., 2008) in an area of the Atlantic rainforest. The present study reports the first occurrence of $O$. burseyi in the state of Minas Gerais, extending its range of occurrence to the Brazilian mainland. The other species recorded in the present study, S. oscari, is a generalist parasite found in the stomach and intestine of different species of South American lizards: Ameiva ameiva, Anolis fuscoauratus, A. punctatus, A. transversalis, E. iheringii, E. perditus, Eurolophosaurus nanuzae, Mabuya agilis, Plica plica, P. umbra, Stenocercus caducus, S. roseiventris, Tropidurus sp. T. guarani, T. spinulosus, T. torquatus and T. melanopleurus (Sousa et al., 2007; Vrcibradic et al., 2008, Ávila \& Silva, 2010).

The present study reports the lowest richness of helminth fauna associated with the gastrointestinal tract of species of Enyalius. Parasites and predators are the first groups to suffer from the environmental impact caused by human activities (Gibb \& Hochuli, 2002; Laurence et al., 2002). The Santa Cândida Municipal Biological Reserve, from which the lizards were sampled, is a small remnant of secondary Atlantic rainforest surrounded by human habitations. In the recent past, this area was covered by coffee plantations. According to McKenzie (2007), changes in anthropogenic land use affect the intermediate host fauna and, consequently, the helminth fauna. Thus, recent changes in the sampling area could have influenced the availability and abundance of prey, which may have reduced the richness of the helminth fauna in comparison to fauna in a typical natural forest (Vrcibradic et al., 2008).

Results of the present study confirm the hypothesis that the intensity of infection increases with the body mass and size of the lizard host, which corroborates findings described in previous studies (Ribas et al., 1995; Sousa et al., 2007). The prevalence of parasites was higher in male lizards than in females. Similar findings are described for Anolis sp. (Vogel \& Bundy, 1987), Cnemidophorus ocellifer (Ribas et al., 1995) and E. perditus (Sousa et al., 2007). However, a greater mean intensity of infection was found in females in the present study, which differs from findings reported for E. perditus by Sousa et al. (2007). This may be explained by local differences in the specific characteristics of the host populations in each study area and the small number of adult female hosts sampled in the present study. Lizards acquire nematodes through the ingestion of arthropods infected with the larvae of these parasites (Goldberg \& Bursey, 1992; Ribas et al., 1995). Thus, gender differences in the prevalence and intensity of helminths may be due to variations in body size and differences in prey consumption in qualitative and/or quantitative terms (Schoener, 1967; Fitch, 1981; Ribas et al., 1995).

The habitat for parasites is not spatially continuous, but rather consists of cells or discrete 'islands', i.e. the hosts represent patches of favourable habitats in an uninhabitable environment. Parasites are also not evenly distributed among these islands. Some hosts contain more parasites than average, others contain less, and many individuals in the population may be free of parasites. Whichever the index of aggregation chosen, the result is usually the same; parasite populations are much more aggregated among their hosts than if the parasites were randomly distributed (Poulin, 1993, 1997). In the present study on the parasite biology of E. perditus, the nematode species exhibited a more aggregated distribution pattern in this host population and O. burseyi was more aggregated than individuals of $S$. oscari.

\section{Acknowledgements}

We thank Dr Reinaldo J. da Silva who facilitated the helminthological analysis at the Laboratório de Parasitologia de Animais Silvestres (LAPAS), UNESP, and to Dr Bernadete M. de Sousa who initially facilitated the dissection of the lizards in one of the laboratories of the Postgraduate Program (PPG), Comportamento e Biologia Animal, UFJF. L.A.A. thanks Fundação de Amparo à Pesquisa do Estado de São Paulo (FAPESP) for financial support (postdoctoral scolarship, \# 2008/50417-7). A.F.B.L. thanks Coordenação de Aperfeiçoamento de Pessoal de Nível Superior (CÁPES), and PPG, Comportamento e Biologia Animal, UFJF for support and facilities. Finally we thank City Hall of Juiz de Fora for permission to access the reserve, to Instituto Brasileiro dos Recursos Naturals Renováveis (IBAMA) for permission to collect the animals (227/2003, Fauna/MG) and to the Comissão de Ética na Experimentação Animal da Pró-Reitoria de Pesquisa, UFJF (47/2003). Finally we thank to Katherine Cameron and the two anonymous referees for providing us with constructive comments and suggestions.

\section{References}

Almeida, W.O., Ribeiro, S.C., Santana, G.G., Vieira, W.L.S., Anjos, L.A. \& Sales, L.D.L. (2009) Lung infection rates in two sympatric Tropiduridae lizard species by pentastomids and nematodes in northeastern Brazil. Brazilian Journal of Biology 69, 963-967.

Anjos, L.A., Rocha, C.F.D., Vrcibradic, D. \& Vicente, J.J. (2005) Helminths of the exotic lizard Hemidactylus mabouia from a rock outcrop area in southeastern Brazil. Journal of Helminthology 79, 307-313.

Ávila, R.W. \& Silva, R.J. (2010) Checklist of helminths from lizards and amphisbaenians (Reptilia, Squamata) of South America. The Journal of Venomous Animals and Toxins including Tropical Diseases 16, 543-572.

Ávila-Pires, T.C.S. (1995) Lizards of Brazilian Amazonia (Reptilia: Squamata). Zoologische Verhandelingen 299, 1-706.

Barreto-Lima, A.F. (2009) Gastric suction as an alternative method in studies of lizard diets: tests for Enyalius 
species (Squamata). Studies on Neotropical Fauna and Environment 44, 23-29.

Bertolotto, C.E.V., Pellegrino, K.C., Rodrigues, M.T. \& Yonenaga-Yassuda, Y. (2002) Comparative cytogenetics and supernumerary chromosomes in the Brazilian lizards genus Enyalius (Squamata, Polychrotidae). Hereditas 136, 51-57.

Bursey, C.R. \& Goldberg, S.R. (2007) New species of Skrjabinodon (Nematoda: Pharyngodonidae) in Uracentron flaviceps (Squamata: Iguanidae) from Ecuador and Peru. Journal of Parasitology 93, 866-869.

Bursey, C.R., Goldberg, S.R. \& Parmelee, J.R. (2005a) Gastrointestinal helminths from 13 species of lizards from Reserva Cuzco Amazónico, Peru. Comparative Parasitology 72, 50-68.

Bursey, C.R., Goldberg, S.R. \& Vitt, L.J. (2005b) New species of Allopharynx (Digenea: Plagiorchiidae) and other helminths in Uranoscodon superciliosus (Squamata: Tropiduridae) from Amazonian Brazil. Journal of Parasitology 91, 1395-1398.

Bush, A.O., Lafferty, K.D., Lotz, J.M. \& Shostak, A.W. (1997) Parasites meet ecology on its own terms: Margolis et al. revisited. Journal of Parasitology 83, 575-583.

Durette-Desset, M.C., Anjos, L.A. \& Vrcibradic, D. (2006) Three new species of the genus Oswaldocruzia Travassos, 1917 (Nematoda, Trichostrongylina, Molineoidea) parasites of Enyalius spp. (Iguanidae) from Brazil. Parasite 13, 115-125.

Etheridge, R. (1969) A review of the iguanid lizard genus Enyalius. Bulletin of the British Museum (Natural History) Zoology (London) 18, 233-260.

Fitch, H.S. (1981) Sexual size differences in reptiles. Miscellaneous Publication of the Museum (Natural History), University of Kansas 70, 1-72.

Freire, M.X.F. (2008) Diversidade de espécies e ecologia da comunidade de um fragmento de Mata Atlântica no nordeste do Brasil. Dissertação de Mestrado, Natal, Brasil.

Freitas, J.F.T. (1955) Nota sobre a fauna helmintológica de répteis brasileiros. Revista Brasileira de Biologia 15, 279-284.

Freitas, J.F.T. (1956) Observações sobre as espécies SulAmericanas do gênero 'Oswaldocruzia' Travassos, 1917. Revista Brasileira de Biologia 16, 309-315.

Gibb, H. \& Hochuli, D.F. (2002) Habitat fragmentation in an urban environment: large and small fragments support different arthropod assemblages. Biological Conservation 106, 91-100.

Goldberg, S.R. \& Bursey, C.R. (1992) Prevalence of the nematode Spauligodon giganticus (Oxyurida: Pharyngodonidae) in neonatal Yarrow's spiny lizards, Sceloporus jarrovii (Sauria: Iguanidae). Journal of Parasitology 78, 539-541.

Goldberg, S.R., Bursey, C.R. \& Tawil, R. (1993) Gastrointestinal helminths of the crevice spiny lizard, Sceloporus poinsettii (Phrynosomatidae). Journal of Helminthological Society (Washington) 60, 263-265.

Goldberg, S.R., Bursey, C.R. \& Cheam, H. (1995) Helminth parasites of three sympatric lizards from Grand Cayman Island, Anolis conspersus, Anolis sagrei (Polychridae) and Leiocephalus carinatus (Tropiduridae). Caribbean Journal of Science 31, 339-340.
Goldberg, S.R., Bursey, C.R. \& Morando, M. (2004) Metazoan endoparasites of 12 species of lizards from Argentina. Comparative Parasitology 71, 208-214.

Jackson, J.F. (1978) Differentiation in the genera Enyalius and Strobilurus (Iguanidae): implications for Pleistocene climatic changes in eastern Brazil. Arquivos de Zoologia (São Paulo) 30, 1-79.

Laurence, W.F., Lovejoy, T.E., Vasconcelos, H.L., Bruna, E.M., Didham, R.K., Stouffer, P.C., Gascon, C., Bierregaard, R.O., Laurence, S.G. \& Sampaio, E. (2002) Ecosystem decay of Amazonian forest fragments: a 22-year investigation. Conservation Biology 16, 605-618.

Lima, A.F.B. \& Sousa, B.M. (2006) Court and copulation behaviors of Enyalius perditus Jackson, 1978 (Sauria: Leiosauridae) in captivity conditions. Revista Brasileira de Zoociências 8, 189-194.

McKenzie, V.J. (2007) Human land use and patterns of parasitism in tropical amphibian hosts. Biological Conservation 137, 102-116.

Poulin, R. (1993) The disparity between observed and uniform distributions: a new look at parasite aggregation. International Journal Parasitology 23, 937-944.

Poulin, R. (1997) Species richness of parasite assemblages: evolution and patterns. Annual Review of Ecology and Systematics 28, 341-358.

Ribas, S.C., Rocha, C.F.D., Teixeira-Filho, P.F. \& Vicente, J.J. (1995) Helminths (Nematoda) of the lizard Cnemidophorus ocellifer (Sauria: Teiidae): assessing the effect of rainfall, body size and sex in the nematode infection rates. Ciência e Cultura 47, 88-91.

Rocha, C.F.D. \& Vrcibradic, D. (2003) Nematode assemblages of some insular and continental lizard hosts of the genus Mabuya Fitzinger (Reptilia, Scincidae) along the eastern Brazilian coast. Revista Brasileira de Zoologia (São Paulo) 20, 755-759.

Rocha, C.F.D., Vrcibradic, D. \& Araújo, A.F.B. (2000) Ecofisiologia de répteis de restingas Brasileiras. pp. 117-149 in Esteves, F.A. \& Lacerda, L.D. (Eds) Ecologia de restingas e lagoas costeiras. Macaé, NUPEM, UFRJ.

Rodrigues, M.T., Freitas, M.A., Silva, T.F.S. \& Bertolotto, C.E.V. (2006) A new species of lizard genus Enyalius (Squamata, Leiosauridae) from the highlands of Chapada Diamantina, state of Bahia, Brazil, with a key to species. Phyllomedusa 5, 11-24.

Rózsa, L., Reiczigel, J. \& Majoros, G. (2000) Quantifying parasites in samples of hosts. Journal of Parasitology 86, 228-232.

Schoener, T.W. (1967) The ecological significance of sexual dimorphism in size in the lizard Anolis conspersus. Science 155, 474-477.

Sociedade Brasileira de Herpetologia (2010) Brazilian reptiles - list of species. Bérnils, R.S. (Org.). Available at website http://www.sbherpetologia.org.br/ (accessed 25 June 2011).

Sousa, B.M. \& Cruz, C.A.G. (2008) Hábitos alimentares de Enyalius perditus (Squamata, Leiosauridae) no Parque Estadual do Ibitipoca, Minas Gerais, Brasil. Iheringia (Série Zoológica) 98, 260-265.

Sousa, B.M., Lima, S.S. \& Oliveira, A. (2007) Gastrointestinal helminth fauna of Enyalius perditus (Reptilia: 
Leiosauridae): relation to host age and sex. Journal of Parasitology 93, 211-213.

Vanzolini, P.E. (1972) Miscellaneous notes on the ecology for some Brazilian lizards (Sauria). Papéis Avulsos de Zoologia (São Paulo) 26, 83-115.

Vanzolini, P.E. (1974) Ecological and geographical distribution of lizards in Pernambuco, northeastern Brasil (Sauria). Papéis Avulsos de Zoologia (São Paulo) 28, 61-90.

Vicente, J.J., Rodrigues, H.O., Gomes, D.C. \& Pinto, R.M. (1993) Nematóides do brasil. Parte III: Nematóides de Répteis. Revista Brasileira de Zoologia 10, 19-168.

Vitt, L.J., Ávila-Pires, T.C.S. \& Zani, P.A. (1996) Observations on the ecology of the rare Amazonian lizard, Enyalius leechii (Polychrotidae). Herpetological Natural History 4, 77-82.
Vogel, P. \& Bundy, D.A.P. (1987) Helminth parasites of Jamaican anoles (Reptilia: Iguanidae): variation in prevalence and intensity with host age and sex in a population of Anolis lineatopus. Parasitology 94, 399-404.

Vrcibradic, D., Vicente, J.J. \& Bursey, C.R. (2007) Helminths infecting the lizard Enyalius bilineatus (Iguanidae, Leiosaurinae), from an Atlantic Rainforest area in Espírito Santo State, southeastern Brazil. Amphibia-Reptilia 28, 166-169.

Vrcibradic, D., Anjos, L.A., Vicente, J.J. \& Bursey, C.R. (2008) Helminth parasites of two sympatric lizards, Enyalius iheringii and E. perditus (Leiosauridae), from an Atlantic Rainforest area of southeastern Brazil. Acta Parasitologica 53, 222-225.

Zar, J.H. (1999) Biostatistical Analysis. 663 pp. New Jersey, Prentice Hall. 